\title{
Effect of different growing media on survival and growth of Grape (Vitus Vinifera) cuttings
}

\author{
Syed Uzair Shah ${ }^{1}$, Qasim Ayub ${ }^{1}$, Ijaz Hussain ${ }^{1}$, Shah Masaud Khan ${ }^{1}$, Shujaat Ali ${ }^{1}$, Muhammad Affan Khan ${ }^{1 *}$, Naveedul \\ $\mathrm{Haq}^{2}$, Abid Mehmood ${ }^{3}$, Touqeer Khan ${ }^{4}$, Nabila Chendouh Brahmi ${ }^{5}$ \\ ${ }^{1}$ Department of Horticulture, The University of Haripur, Pakistan \\ ${ }_{2}$ Department of Food Science and Technology, The University of Haripur, Pakistan \\ ${ }^{3}$ Department of Agronomy, The University of Haripur, Pakistan \\ ${ }^{4}$ Department of Soil Science, The University of Haripur, Pakistan \\ ${ }^{5}$ Laboratory of 3BS, Faculty of Life and Nature Sciences, University of Bejaia, 06000, Bejaia, Algeria \\ email: maffankhan@uoh.edu.pk
}

\begin{abstract}
Propagation through hardwood cutting is a common method adopted by farmers and nursery workers to commercialize grape plants. The survival, success, and vigor of the cutting depend upon many factors. The growing media plays a crucial role because it serves as a basic supplier of mineral nutrients and provides support to the growing roots, hence keeping in view the importance of growing media current experiment was conducted to evaluate the performance of grape cultivars in different growing media at Department of Horticulture, The University of Haripur, during January-April 2020. Hardwood cutting of two grape cultivar Sundar Khani and Thompson were planted in ten different media viz; Compost,Sand, Soil, Farmyard manure (FYM), and mixture of Soil + Sand(1:1), Compost + Soil(1:1), FYM + Soil(1:1), Sand + Compost(1:1), Sand + FYM(1:1), and Compost + FYM(1:1). The results showed that the highest survival percentage $(90 \%)$, shoot length $(30.83 \mathrm{~cm})$, number of leaves $(18.83)$, root length $(13.66 \mathrm{~cm})$, and number of roots (14.50) were recorded in Compost while, maximum days to emergence (17.5) and mortality percentage (59.8\%) were recorded in FYM and Soil, respectively. Sundar Khani showed the highest days to emergence (11.4), mortality percentage (29.63\%), root length $(9.03 \mathrm{~cm})$, number of roots (32.33), while grape variety Thompson showed the highest sprouting percentage (79.9\%), shoot length (19.63cm) and number of leaves (11.1). Hence, it is concluded that among different growing media, Compost showed promising results, and Thompson showed the highest survival percentage that can be used for commercial purposes.
\end{abstract}

Keywords: Asexual propagation, Survival, Grapes, Growing media, Haripur

\section{Highlights:}

$>\quad$ Propagation through woodcutting for commercializing grape plants

$>\quad$ importance of growing media on commercializing grape plants

$>\quad$ use of ten different growing media on commercializing grape plants

$>\quad$ Compost found best for commercializing grape plants

\section{INTRODUCTION}

Grapes (Vitus vinifera) belong to the family Vitaceae are berry fruits grown on vines. This family consists of 14 living genera and thousands of domesticated and wild species. Grapes are among the most popular fruits in the commons and are valuable for human health. Vitis vinifera, also known as European grapes, are domesticated between the Black Sea and the Caspian Sea. Historians believed that these grapes were first introduced in Europe and then to all the continents by different explorers (Anonymous 2008). Grapes are widely grown to make wines, eat fresh as table grapes, and make raisins. Different studies showed that grapes consumption could reduce the risk of cancer development, heart strokes, blood pressure, and different allergies and constipation (Abebe 2017). Grapes are also a rich source of many vital nutrients like boron which promotes healthy bone growth (Demir and Serindağ 2006).

Vegetative propagation through stem cutting is the most common method for planting and obtaining good plants in the horticulture industry. This method is extensively implemented in the propagation of grapes. Propagation through stem cutting has many advantages like economic, lesser space requirements, simplicity of the method, and above all, production of true-to-type plants in a short time (Alikhani et al., 2011). Propagation through stem cutting maintains true to type varietal characteristics (Waite et al., 2015). Many fruit plants like grapes, figs, pomegranate, etc., are being propagated using stem cuttings from ancient times. This method is suitable for container plantation as it provides relaxed marketing, is suitable for a more extended plantation period, and is easy to transport (Mhango et al., 2008). 
Potting media is among one of the main factors for the success and health of stem cuttings. A potting media supports the growing plant, sustains moisture, provides water and nutrients to plants, and helps exchange gases at the root zone (Larsen and Andreasen 2004). A potting or growing medium allows cuttings to grow and extract nutrients that help in producing healthy seedlings. Along with physical properties, the media's biological activity and Physico-chemical profile can alter the growth and development of cuttings. A potting media with suitable drainage, appropriate water holding capacity, suitable amounts of soil microbes, and porosity is considered best for raising healthy plants (Ahmad et al., 2004).

Using soil as potting media for the propagation of grapes through stem cutting is common among farmers and nursery workers. Soil generally lacks appropriate physical and chemical characteristics and has lower vital nutrients, resulting in inferior quality seedlings. Hence it is of utmost importance to choose a suitable potting media to achieve healthy seedlings as it serves as a critical source of nutrition and provides a root system to grow plants. Still, the knowledge about potting media is very limited in the farmer community and nursery growers. So, there is a need to optimize protocols for potting media by using cheap sources available at local premises and are readily available in large amounts. Hence this study was undertaken to evaluate the performance of different potting media on stem cuttings of grapes and to identify a suitable potting media for grapes cutting.

\section{MATERIAL AND METHODS}

A pot experiment was conducted at Horticulture Nursery Farm, the University of Haripur, to evaluate the effect of different growing media on the growth and survival of grape cuttings during the months of January-April 2020. The experiment was arranged in CRD (Complete Randomized Design) with two factors, i.e., grape varieties and growing media. Each experimental unit was replicated 3 times. Hardwood cuttings of two commercially important grapes, i.e., Sundar Khani and Thompson, were collected from three-year-old healthy mother plants. Each cutting was 10-15cm long with 2 to 3 nodes. Ten different types of growing media were used in the present study, which was; Compost, Sand, Soil, and FYM along with a mixture of Soil + Sand (1:1), Compost + Soil (1:1), FYM + Soil (1:1), Sand + Compost (1:1), Sand + FYM (1:1), Compost + FYM(1:1). Each potting media were then put into polythene bags of equal size. Each bag was taken as single replication, and one grape cutting per bag was planted and kept in the plastic tunnel for protection against weather fluctuations. Data from each replication were collected, and means were calculated. Statistical differences were calculated by using STATIX 8.1 at $5 \%$ probability level.

\subsection{Diverse parameters of the grape varieties under different media}

The following parameters were recorded during the study;

i. Days to emergence: Days to emergence were calculated by counting the total number of days from the sowing of cuttings to the emergence of leaves from each treatment.

ii. Sprouting Percentage (\%): The total number of plants that emerged in each media was counted, and the survival percentage was calculated using the following formula.

$$
\text { Survival percentage }(\%)=(\text { number of sprouted cuttings } / \text { number of cuttings planted }) \times 100
$$

iii. Mortality Percentage (\%): Mortality percentage was observed throughout the whole experimental process and computed with the help of the following formula.

$$
\text { Mortality percentage }(\%)=\text { number of died cuttings } / \text { number of cuttings planted } \mathrm{x} 100
$$

iv. Shoot length (cm): Shoot length was measured from the base of the shoot to the tip of the shoot with the help of a ruler.

v. Root length (cm): Length of longest root from apex to tip was measured using a ruler.

vi. Number of leaves per cutting: The total number of leaves from each replication was counted, and means were calculated.

vii. Number of roots per cutting: Plants from each treatment were uprooted and washed extensively with tap water to remove all the mud and media particles from the roots and then were kept on tissue paper for drying and to absorb all the water. Then after drying, a total number of roots were counted, and means were calculated. 


\section{RESULTS AND DISCUSSIONS}

\subsection{Days to emergence}

Data regarding days to emergence reveals that the highest days to emergence (17.5 days) were recorded in FYM, whereas the least days to emergence (6.6 days) in Compost. A non-significant variation regarding days to emergence was noted among both tested varieties of grapes. The interactive results of media and grape varieties indicate that the highest days to emergence (17.6 days) were recorded in Thompson when sown in FYM. Meanwhile, the least days to emergence (6.3 days) were noted in Thompson's Compost and grape. These results (Table 1) are in agreement with the findings of Antunes et al. (2001) and indicate that those cuttings which were planted in Compost are the first to emerge among other cuttings. This may be attributed to high porosity and higher availability of moisture and nutrients to the cutting in Soil, which enhances the physiological activity of grape cuttings and results in the early emergence of leaves compared to other potting media (Jamil et al., 2016). The delayed emergence of leaves in FYM can be attributed to the fact that although FYM possesses the highest reservoirs of nutrients, lower water holding capacity and moisture retention of the said media have failed to prevent grape cuttings from moisture stress and thus delayed the bud initiation process.

Table-1: Effect of growing media on days to emergence of grape cuttings

\begin{tabular}{lccc}
\hline \multirow{2}{*}{ Media } & \multicolumn{2}{c}{ Varieties } & \multirow{2}{*}{ Means } \\
\cline { 2 - 3 } & Sundar Khani & Thompson & \\
\hline Compost & $7 \mathrm{kl}$ & 6.331 & $6.66 \mathrm{i}$ \\
Sand & $8.00 \mathrm{ijk}$ & $7.33 \mathrm{jkl}$ & $7.66 \mathrm{~h}$ \\
Soil & $16.33 \mathrm{bc}$ & $16 \mathrm{c}$ & $16.16 \mathrm{~b}$ \\
FYM & $17.33 \mathrm{ab}$ & $17.66 \mathrm{a}$ & $17.50 \mathrm{a}$ \\
Soil + Sand(1:1) & $7.33 \mathrm{jkl}$ & $7.33 \mathrm{jkl}$ & $7.333 \mathrm{hi}$ \\
Compost + Soil(1:1) & $14.33 \mathrm{de}$ & $14.66 \mathrm{~d}$ & $14.50 \mathrm{c}$ \\
FYM + Soil(1:1) & $8.33 \mathrm{hij}$ & $8.66 \mathrm{ghi}$ & $8.50 \mathrm{~g}$ \\
Sand + Compost(1:1) & $12.33 \mathrm{f}$ & $12.33 \mathrm{f}$ & $12.33 \mathrm{e}$ \\
Sand + FYM(1:1) & $9.66 \mathrm{~g}$ & $9.33 \mathrm{gh}$ & $9.50 \mathrm{f}$ \\
Compost + FYM(1:1) & $13.33 \mathrm{ef}$ & $13.33 \mathrm{ef}$ & $13.33 \mathrm{~d}$ \\
Means & $11.40 \mathrm{a}$ & $11.30 \mathrm{a}$ & \\
\hline
\end{tabular}

Critical value of comparison ( $L S D=0.05)$ for Media $=0.782$, for Variety=0.350, and for interaction Media $x$ Variety $=1.106$

\subsection{Sprouting percentage $(\%)$}

Results related to the sprouting percentage showed that statistically significant differences were recorded in growing media and grape varieties. In contrast, a non-significant difference was noted in the interaction between grape varieties and growing media. The highest sprouting percentage (90\%) was found in plants grown in Compost; meanwhile, the lowest sprouting percentage (40\%) was shown in Soil. Grape variety Thompson showed the highest sprouting percentage (70.93\%), whereas the least sprouting percentage $(70.36 \%)$ was found in Sundar Khani. The interactive results of growing media and grape varieties showed that the highest sprouting percentage (90.33\%) was given by Sundar Khani when sown in Compost. In contrast, the least sprouting percentage (33.9\%) was noted by Sundar Khani when grown in Soil. Similar findings have been previously reported in African breadfruit, jojoba, mango, kiwi fruit, and Kagzi lime (Baiyeri 2003; Bashir et al., 2009; Parasana et al., 2013; Irshad et al., 2014; Mishra 2014).

Results reported in Table 2 indicate that the highest survival percentage was recorded in Soil which can be attributed to the fact that Compost might have delivered favorable conditions to grape cuttings and supplied sufficient mineral nutrients to grapes cuttings which were needed for enzyme initiation and to enhance the biochemical process as compared to other media and combinations (Wazir et al., 2003). The survival and growth of stem cutting of any plant chiefly depend upon the quality of roots, the number of roots, and length of roots, the more enhanced quality of roots results in the absorption of food materials and water from the potting media, which in turn increase the survival of cutting (Mishra, 2014). It also increased cuttings' potential to fight against different stresses and prevent cuttings from adverse agro-climatic conditions (Table 2). 
Table-2: Effect of growing media on sprouting percentage of grape cuttings.

\begin{tabular}{|c|c|c|c|}
\hline \multirow{2}{*}{ Media } & \multicolumn{2}{|c|}{ Varieties } & \multirow{2}{*}{ Means } \\
\hline & Sundar Khani & Thompson & \\
\hline Compost & 90.33a & $89.66 a$ & $90 \mathrm{a}$ \\
\hline Sand & $84.33 b c$ & $85 b$ & $84.66 \mathrm{~b}$ \\
\hline Soil & $39.66 \mathrm{k}$ & $40.66 \mathrm{k}$ & $40.16 \mathrm{i}$ \\
\hline FYM & $44 j$ & $44 j$ & $44 \mathrm{~h}$ \\
\hline Soil + Sand (1:1) & $82.33 \mathrm{~d}$ & $82.66 \mathrm{~cd}$ & $82.50 \mathrm{c}$ \\
\hline Compost + Soil(1:1) & $61.33 \mathrm{i}$ & $63.66 \mathrm{~h}$ & $62.50 \mathrm{~g}$ \\
\hline FYM + Soil $(1: 1)$ & $80.33 \mathrm{e}$ & $81 \mathrm{de}$ & $80.66 \mathrm{~d}$ \\
\hline Sand + Compost $(1: 1)$ & $67.66 \mathrm{~g}$ & $68.33 \mathrm{~g}$ & $68 \mathrm{f}$ \\
\hline Sand + FYM(1:1) & $82 \mathrm{de}$ & $82.33 \mathrm{~d}$ & $82.16 \mathrm{c}$ \\
\hline Compost + FYM(1:1) & $71.66 f$ & $72 \mathrm{f}$ & $71.83 \mathrm{e}$ \\
\hline Means & $70.36 \mathrm{~b}$ & $70.93 \mathrm{a}$ & \\
\hline
\end{tabular}

\subsection{Mortality percentage (\%)}

Results of mortality percentage (Table 3 ) reveals that the highest mortality percentage $(59.8 \%)$ was recorded in soil, whereas the most negligible mortality percentage (10\%) was in Compost. Grape variety Sundar Khani showed a maximum mortality percentage $(29.6 \%)$, whereas the lowest mortality percentage $(29.0 \%)$ was recorded in Thompson (Table 3). The interactive results of media and grape varieties indicate that the highest mortality percentage (60.3\%) was recorded in Sundar Khani when sown in Soil. In contrast, the least mortality percentage (10.3\%) was noted in the grape variety Thompson when sown in Compost. These findings partially correspond with those of Farooq et al. (2018). The highest mortality percentage in the soil might be due to more compactness and the poor nutritional status of soil media. The survival, proper growth, and development of planted cuttings depend upon the physical and chemical composition of the growing media. Low chemical or physical profile of the media can lead to abnormal or stunted growth of roots which reduces the absorption of nutrients and water by roots and thus lead to moisture stress, dehydration, and lower nutrition levels inside the sprouting cutting.

Table-3: Effect of growing media on mortality percentage of grape cuttings

\begin{tabular}{|c|c|c|c|}
\hline \multirow{2}{*}{ Media } & \multicolumn{2}{|c|}{ Varieties } & \multirow{2}{*}{ Means } \\
\hline & Sundar Khani & Thompson & \\
\hline Compost & $9.66 \mathrm{k}$ & $10.33 \mathrm{k}$ & $10 \mathrm{i}$ \\
\hline Sand & $15.66 \mathrm{ij}$ & $15 \mathrm{j}$ & $15.33 \mathrm{~h}$ \\
\hline Soil & $60.33 \mathrm{a}$ & $59.33 \mathrm{a}$ & $59.83 a$ \\
\hline FYM & $56 \mathrm{~b}$ & $56 \mathrm{~b}$ & $56 \mathrm{~b}$ \\
\hline Soil + Sand(1:1) & $17.66 \mathrm{~h}$ & $17.33 \mathrm{hi}$ & $17.50 \mathrm{~g}$ \\
\hline Compost + Soil(1:1) & $38.66 \mathrm{c}$ & $36.66 \mathrm{~d}$ & $37.50 \mathrm{c}$ \\
\hline FYM + Soil $(1: 1)$ & $19.66 \mathrm{~g}$ & $19 \mathrm{gh}$ & $19.33 \mathrm{f}$ \\
\hline Sand + Compost(1:1) & $32.33 \mathrm{e}$ & $31.66 \mathrm{e}$ & $32 d$ \\
\hline Sand + FYM(1:1) & $18 \mathrm{gh}$ & $17.66 \mathrm{~h}$ & $17.83 \mathrm{~g}$ \\
\hline Compost + FYM(1:1) & $28.33 \mathrm{f}$ & $28 \mathrm{f}$ & $28.16 \mathrm{e}$ \\
\hline Means & $29.63 \mathrm{a}$ & $29.06 \mathrm{~b}$ & \\
\hline
\end{tabular}

\subsection{Shoot length $(\mathrm{cm})$}

Results of shoot length (Table 4) revealed that statistically significant difference in growing media and the interaction of growing media and grape varieties; conversely, non-significant differences were noted in grape varieties. The highest shoot length $(30.83 \mathrm{~cm})$ was found in compost plants, whereas the lowest shoot length $(3.66 \mathrm{~cm})$ was shown by grapes cuttings sown in Soil and FYM. The interactive results of growing media and grape varieties showed that the highest shoot length $(31 \mathrm{~cm})$ was given by Thompson when sown in Compost. In contrast, the most petite shoot length $(3.33 \mathrm{~cm})$ was recorded in Sundar Khani when grown in FYM. These results are in close conformity with Baiyeri (2003) in cashew plant, Parasana et al., (2013) in mango, and Adugna et al., (2015) in vanilla. The highest shoot length in Compost can be due to higher nutritional levels of the Compost, higher water retention capabilities, suitable drainage, and higher porosity, which help in the development of optimal root system and enable plants to absorb more water and nutrition, all these factors enhanced the meristematic activity of the cuttings which triggered the division of cambial cells and tissue (Bashir et al., 2009; Ahmad and Qasim, 2003). 
Table-4: Effect of growing media on shoot length of grape cuttings

\begin{tabular}{lccc}
\hline \multirow{2}{*}{ Media } & \multicolumn{2}{c}{ Varieties } & \multirow{2}{*}{ Means } \\
\cline { 2 - 3 } & Sundar Khani & Thompson & \\
\hline Compost & $30.66 \mathrm{a}$ & $31 \mathrm{a}$ & $30.83 \mathrm{a}$ \\
Sand & $28.33 \mathrm{~b}$ & $29.66 \mathrm{ab}$ & $29 \mathrm{~b}$ \\
Soil & $3.66 \mathrm{i}$ & $3.66 \mathrm{i}$ & $3.66 \mathrm{~h}$ \\
FYM & $3.33 \mathrm{i}$ & $4 \mathrm{i}$ & $3.66 \mathrm{~h}$ \\
Soil + Sand(1:1) & $25.33 \mathrm{~cd}$ & $26.33 \mathrm{c}$ & $25.83 \mathrm{c}$ \\
Compost + Soil(1:1) & $14 \mathrm{~h}$ & $13.33 \mathrm{~h}$ & $13.66 \mathrm{~g}$ \\
FYM + Soil( $(1: 1)$ & $24.66 \mathrm{cde}$ & $24.66 \mathrm{cde}$ & $24.66 \mathrm{~cd}$ \\
Sand + Compost $(1: 1)$ & $18.66 \mathrm{~g}$ & $22.66 \mathrm{f}$ & $20.66 \mathrm{e}$ \\
Sand + FYM(1:1) & $24 \mathrm{def}$ & $23.33 \mathrm{ef}$ & $23.66 \mathrm{~d}$ \\
Compost + FYM(1:1) & $18.66 \mathrm{~g}$ & $17.66 \mathrm{~g}$ & $18.16 \mathrm{f}$ \\
Means & $19.13 \mathrm{a}$ & $19.63 \mathrm{a}$ & \\
\hline Critical value of comparison $(\boldsymbol{L S} \boldsymbol{D}=\mathbf{0 . 0 5})$ for Media $=\mathbf{1 . 2 9 2}$, Variety $=\mathbf{0 . 5 7 7 , ~ M e d i a x V a r i e t y ~}=\mathbf{1 . 8 2 7}$
\end{tabular}

\subsection{Number of leaves per cutting}

The number of leaves in different growing media was presented in Table 5. The statistically significant difference was recorded in growing media; conversely, non-significant differences were noted in grape varieties and interaction between growing media and grape varieties. The highest number of leaves (18.83) was found in grapes cutting sown in Compost, whereas the lowest number of leaves (2.33) was shown in soil. Grape variety Thompson showed the highest number of leaves (11.1); meanwhile, the least number of leaves (11.03) was found in Sundar Khani. The interactive results of growing media and grape varieties showed that the highest number of leaves (19) was given by Thompson when sown in Compost, whereas least (2.33) by Thompson and Sundar Khani when grown in Soil.

The number of photosynthetically active leaves depends upon the better root and shoot growth, which relies on biological and physical characteristics of the potting media. The bud opening depends upon the biochemical process occurring inside the stem and bud cells; appropriate levels of minerals and nutrients inside the plant allow to form new and to open dormant buds. As by previous results, Compost has increased the number of roots and shoots, which might be a reason to increase the number of leaves in grape cutting.

Table-5: Effect of growing media on Number of leaves of grape cuttings

\begin{tabular}{lccc}
\hline \multirow{2}{*}{ Media } & \multicolumn{2}{c}{ Varieties } & \multirow{2}{*}{ Means } \\
\hline Compost & $18.66 \mathrm{a}$ & $19 \mathrm{a}$ & $18.83 \mathrm{a}$ \\
Sand & $17.66 \mathrm{bc}$ & $18.33 \mathrm{ab}$ & $18 \mathrm{~b}$ \\
Soil & 2.331 & 2.331 & $2.33 \mathrm{j}$ \\
FYM & $3.66 \mathrm{k}$ & $3.66 \mathrm{k}$ & $3.66 \mathrm{i}$ \\
Soil + Sand(1:1) & $17.33 \mathrm{~cd}$ & $16.66 \mathrm{de}$ & $17 \mathrm{c}$ \\
Compost + Soil $(1: 1)$ & $5.33 \mathrm{j}$ & $5.33 \mathrm{j}$ & $5.33 \mathrm{~h}$ \\
FYM + Soil(1:1) & $15.66 \mathrm{f}$ & $16 \mathrm{ef}$ & $15.83 \mathrm{~d}$ \\
Sand + Compost(1:1) & $6.66 \mathrm{i}$ & $6.66 \mathrm{i}$ & $6.66 \mathrm{~g}$ \\
Sand + FYM(1:1) & $14.66 \mathrm{~g}$ & $14.33 \mathrm{~g}$ & $14.50 \mathrm{e}$ \\
Compost + FYM(1:1) & $8.33 \mathrm{~h}$ & $8.66 \mathrm{~h}$ & $8.50 \mathrm{f}$ \\
Means & $11.03 \mathrm{a}$ & $11.10 \mathrm{a}$ & \\
\hline Critical value of comparison $(\boldsymbol{L S D}=\mathbf{0 . 0 5})$ for Media $=\mathbf{0 . 7 0 6 , ~ V a r i e t y ~}=\mathbf{0 . 3 1 5}$, Mediax Variety $=\mathbf{0 . 9 9 8}$
\end{tabular}

\subsection{Root length (cm)}

The root length in all growing media is reported in Table 6. It was observed that statistically significant difference was recorded in growing media; on the other hand, non-significant differences were noted in grape varieties and interaction between growing media and grape varieties. The highest root length $(13.66 \mathrm{~cm})$ was found in compost plants, whereas the lowest root length $(3.16 \mathrm{~cm})$ was shown in FYM. Grape variety Sundar Khani showed the highest root length $(9.03 \mathrm{~cm})$; meanwhile, the least root length $(9 \mathrm{~cm})$ was found in Thompson. The interactive results of growing media and grape varieties showed that the highest root length $(13.66 \mathrm{~cm})$ was given by Sundar Khani and Thompson when sown in Compost, whereas least by Sundar Khani when grown in FYM. The current results confirm the reports of Venkatesan et al. (2010) and Choeichit et al. (2013) in stem cuttings of Gymnema sylvestre and cassava, respectively. The highest number of roots in 
Compost is related to the higher electrical conductivity values, higher water and nutrient retention abilities, supply of adequate aeration, and presence of beneficial growth-regulating substances like micro-organisms (Moradi et al., 2014). It was noted that the performance of soil in terms of root development was unsatisfactory. The length of roots depends upon their ability to penetrate in growing media, which in turn depends upon the porosity of the media; the more significant the porosity, the greater the penetration, and the greater the length of the root. Thus, due to the compact nature of Soil and less porosity, it hindered the growth and penetration of roots which were also reported by Mehmood et al. (2013) in Floral Shower (Antirrhinum majus L.).

Table-6: Effect of growing media on root length of grape cuttings

\begin{tabular}{|c|c|c|c|}
\hline \multirow{2}{*}{ Media } & \multicolumn{2}{|c|}{ Varieties } & \multirow{2}{*}{ Means } \\
\hline & Sundar Khani & Thompson & \\
\hline Compost & $13.66 \mathrm{a}$ & $13.66 \mathrm{a}$ & $13.66 \mathrm{a}$ \\
\hline Sand & $13 a b c$ & $12 \mathrm{~cd}$ & $12.50 \mathrm{~b}$ \\
\hline Soil & $3.66 \mathrm{~g}$ & $3 \mathrm{~g}$ & $3.33 \mathrm{f}$ \\
\hline FYM & $3 \mathrm{~g}$ & $3.33 \mathrm{~g}$ & $3.16 \mathrm{f}$ \\
\hline Soil + Sand $(1: 1)$ & $11.33 \mathrm{~d}$ & $12.33 \mathrm{bcd}$ & $11.83 b$ \\
\hline Compost + Soil(1:1) & $5.66 \mathrm{f}$ & $5.66 \mathrm{f}$ & $5.66 \mathrm{e}$ \\
\hline FYM + Soil $(1: 1)$ & $13.33 \mathrm{ab}$ & $13.33 \mathrm{ab}$ & $13.33 \mathrm{a}$ \\
\hline Sand + Compost $(1: 1)$ & $6.66 \mathrm{ef}$ & $6.66 \mathrm{ef}$ & $6.66 \mathrm{~d}$ \\
\hline Sand + FYM(1:1) & $12.33 \mathrm{bcd}$ & $12.33 \mathrm{bcd}$ & $12.33 \mathrm{~b}$ \\
\hline Compost + FYM(1:1) & $7.66 \mathrm{e}$ & $7.66 \mathrm{e}$ & $7.66 \mathrm{c}$ \\
\hline Means & $9.03 \mathrm{a}$ & $9 \mathrm{a}$ & \\
\hline
\end{tabular}

\subsection{Number of roots per cutting}

The highest number of roots (49.50) was found in plants grown in Compost, closely followed by sand (48.33), whereas the lowest number of roots (4.33) was shown by Soil. Grape variety Thompson showed the highest number of roots (32.33); meanwhile, the least number of roots (32.06) was found in Sundar Khani. The interactive results of growing media and grape varieties showed that the highest number of roots (49.66) were given by Sundar Khani when sown in Compost, whereas least (7) by Thompson when grown in Soil. These results are in accordance with those of Singh and Nair (2003) for grapes and by Irshad et al. (2014) in kiwi fruit, who also noted that cutting which is sown in Soil had produced a higher number of roots. The present study confirmed that Compost and sand had increased the number of roots in grape cuttings due to these media's improved physical, chemical, and biological properties (Arancon et al., 2005). The enhanced number of roots in Compost and sand is related to improved gaseous exchanges, admirable drainage, and presence of high organic matter, and good water holding capacity; all these factors contributed to increased cell division of callus, which increased the formation of tissues like phloem, pericycle, and cambium. These tissues formed the primordial of roots, which created a vascular connection with conducting tissues of cuttings through the cortex and epidermis; as a result, roots developed in the given medium (Table 7).

Table-7; Effect of growing media on Number of roots of grape cuttings

\begin{tabular}{lccc}
\hline \multirow{2}{*}{ Media } & \multicolumn{2}{c}{ Varieties } & \multirow{2}{*}{ Means } \\
\cline { 2 - 3 } & Sundar Khani & Thompson & \\
\hline Compost & $49.66 \mathrm{a}$ & $49.33 \mathrm{ab}$ & $49.50 \mathrm{a}$ \\
Sand & $49 \mathrm{ab}$ & $48.33 \mathrm{~b}$ & $48.66 \mathrm{a}$ \\
Soil & $4.33 \mathrm{~m}$ & $4.33 \mathrm{~m}$ & $4.33 \mathrm{~g}$ \\
FYM & 6.661 & 71 & $6.83 \mathrm{f}$ \\
Soil + Sand(1:1) & $45.33 \mathrm{c}$ & $44.66 \mathrm{~cd}$ & $45 \mathrm{~b}$ \\
Compost + Soil(1:1) & $25.33 \mathrm{j}$ & $25 \mathrm{~J}$ & $25.16 \mathrm{e}$ \\
FYM + Soil(1:1) & $43.66 \mathrm{de}$ & $42.66 \mathrm{ef}$ & $43.16 \mathrm{c}$ \\
Sand + Compost(1:1) & $23.33 \mathrm{k}$ & $27 \mathrm{i}$ & $25.16 \mathrm{e}$ \\
Sand + FYM(1:1) & $42.33 \mathrm{f}$ & $42.33 \mathrm{f}$ & $42.33 \mathrm{c}$ \\
Compost + FYM(1:1) & $31 \mathrm{~h}$ & $32.66 \mathrm{~g}$ & $31.83 \mathrm{~d}$ \\
Means & $32.06 \mathrm{a}$ & $32.33 \mathrm{a}$ & \\
\hline Critical value of comparison $(\boldsymbol{L S D = 0 . 0 5 )}$ for Media $\mathbf{= 0 . 8 4 5}$, Variety=0.378, MediaxVariety $=\mathbf{1 . 1 9 6}$
\end{tabular}




\section{CONCLUSION}

The current experiment concluded that different growing media had imparted a significant difference on all studied parameters of the grape cuttings and the overall growth of grape cultivars. Among both grape cultivars, Sundar Khani performed better in the climatic conditions of Haripur. Furthermore, it was observed that among all the media, Compost had significantly increased all the parameters. In contrast, Soil and FYM failed to impart a significant effect on the growth and survival of grape cuttings.

\section{Recommendations}

Among different media, it is recommended that Nurserymen should use Compost for successful commercial production of healthy grape plants. Based on the present investigation, grape cultivars should use Sunder Khani for commercial purposes.

\section{Acknowledgment}

The authors are thankful to the Dean Faculty of the University of Haripur for providing support during the whole period of the experiment

\section{Conflict of interest}

It is declared that there is no conflict of interest between the Authors of this paper

\section{References}

Abebe, H., (2017). Effect of cane length and rooting media on rooting and shoot growth of grape (vitis vinifera L.) stem cuttings at raya valley, northern Ethiopia (Doctoral dissertation, Hawassa University).

Ahmad, I., \& Qasim, M. (2003). Influence of various potting media on growth and nutrient uptake efficiency of Scindapsus aureus. Int. J. Agric. Biol, 5, 594-597.

Ahmad, W., Junaid, M., Nafees, M., Farooq, M. and Saleem, B.A., (2004). Effect of pruning severity on growth behavior of spur and bunch morphology of grapes (Vitis vinifera L.) cv. Perlette. International Journal of Agriculture and Biology, 6(1), pp.160-161.

Alikhani, L., Ansari, K., JAMNEJAD, M. and Tabatabaie, Z., (2011). The effect of different mediums and cuttings on growth and rooting of pomegranate cuttings. Iranian Journal of Plant Physiology 1(3), pp.199-203 .

Anonymous 2008 Grapes_-Vitis spp. (2008). http:==www.uga.edu=fruit=grape.html (accessed February 20, 2008).

Antunes, L.E.C., Chalfun, N.N.J., Pasqual, M., Dutra, L.F. and Cavalcante-Alves, J.M., (2001), May. Factors affecting on rooting of figs (Ficus Carica L.) cuttings. In II International Symposium on Fig 605 (pp. 141-146).

Arancon, N.Q. and Edwards, C.A., (2005). Effects of vermicomposts on plant growth. Soil Ecology Laboratory, The Ohio State University, Columbus, $\mathrm{OH}, 43210$, pp.16-18.

Baiyeri, K.P., (2003). Evaluation of nursery media for seedling emergence and early seedling growth of two tropical tree species. Moor Journal of Agriculture Research 4(1), pp.60-65.

Bashir, M.A., Ahmad, M., Anjum, M.A., (2009). Effect of various potting media on growth of rooted Jojoba (Simmondsia chinensis) Cuttings. International Journalof Agriculture Biology 9(1), pp. 147-151

Choeichit, J., Boonthai Iwai, C., Ta-Oun, M., (2013). PrePlanting treatments of stem cutting with vermicompost tea affecting rooting and growth yields of different cassava varieties. International Journal of Environment and Rural Development 4(1), pp. 179-182.

Demir, B.S. and Serindăg, O., (2006). Determination of Boron in Grape (Vitis vinifera) by Azomethine $\mathrm{H}$ Spectrophotometric Method. Eurasian Journal of Analytical Chemistry, 1(1). 
Farooq, M., Kakar, K., Golly, M.K., Ilyas, N., Zib, B., Khan, S., Khan, I., Saboor, A. and Bakhtiar, M., (2018) Comparative Effect of Potting Media on Sprouting and Seedling Growth of Grape Cuttings. International Journal of Environmental and Agriculture Research, 4(3).

Irshad, M., Rab, A., Rahman, J., Sajid, M., Khan, I., Ali, S., Razaq, M., Sallahuddin, M., (2014). Influence of different planting dates and media on growth of Kiwi (Cv. Hayward) cuttings. Sarhad Journal of Agriculture 30(4), pp.419-424.

Jamil, M.K., Rahman, M.M., Hossain, M.M., Hossain, M.T. and Karim, A.S., (2016). Effect of Potting Media on Growth, Flowering and Bulb Production of Hippeastrum (Hippeastrumhybridum Hort.). International Journal of Applied Sciences and Biotechnology, 4(3), pp.259-271.

Larsen, S.U. and C. Andreasen, (2004). Light and heavy turfgrass seeds differ in germination percentage and mean germination thermal time. Crop Science, 44(5): pp. 1710-1720.

Mehmood, T., Ahmad, W., Ahmad, K.S., Shafi, J., Shehzad, M.A., Sarwar, M.A., (2013). Comparative effect of different potting media on vegetative and reproductive growth of floral shower (Antirrhinum majus L.). Universal Journal of Plant Science 1(3), pp.104-111.

Mhango, J., Akinnifesi, F.K., Mng'omba, S.A. and Sileshi, G., (2008). Effect of growing medium on early growth and survival of Uapaca kirkiana Müell Arg. seedlings in Malawi. African Journal of Biotechnology, 7(13) pp. 2197-2202

Mishra, S., (2014). Effect of different rooting media on survival and success of air layers in kagzilime. Annals of Plant and Soil Research 16(3), pp/ 264-267.

Moradi, H., Fahramand, M., Sobhkhizi, A., Adibian, M., Noori, M., abdollahi, S., Rigi, K., (2014). Effect of vermicompost on plant growth and its relationship with soil properties. International Journal of Farming and Allied Science 3(3), pp.333338.

Parasana, J.S., Leua, H.N., Ray, N.R., (2013). Effect of different growing medias mixture on the germination and seedling growth of mango (Mangifera indica) cultivars under net house conditions. International Journal of Life science 8(3), pp.897-900

Singh DR, Nair SA (2003). Standardization of rooting media for cuttings of certain house plants; Journal of Ornamental Horticulture 6(1): 78-79.

Venkatesan, S., Sudhagar, R., Shakila, A., (2010). Effect of potting media and azospirillum on the rooting of Gymnemasy lvestre cuttings. Asian Journal of Horticulture 5(2), pp.260-262

Waite, H., Whitelaw-Weckert, M. and Torley, P., (2015). Grapevine propagation: principles and methods for the production of high-quality grapevine planting material. New Zealand Journal of Crop and Horticultural Science, 43(2), pp.144-161

Wazir, M.G., Ishtiaq, M., Aziz, A. and Khan, I.A. (2003). Effects of different soil media on the growth of Dracaena dermensis var. Janet Craige cuttings. Sarhad Journal of Agriculture 19, pp 31-40

Received: $27^{\text {th }}$ June, 2021

Accepted: 21 ${ }^{\text {nd }}$ August, 2021 